Article

\title{
New Anti-Inflammatory Aromatic Components from Antrodia camphorata
}

\section{Yu-Chang Chen ${ }^{1}$, His-Lin Chiu ${ }^{1}$, Che-Yi Chao ${ }^{2}$, Wen-Hsin Lin ${ }^{3}$, Louis Kuoping Chao ${ }^{4}$, Guan-Jhong Huang ${ }^{1, *}$ and Yueh-Hsiung Kuo ${ }^{1,5, *}$}

1 Department of Chinese Pharmaceutical Sciences and Chinese Medicine Resources, College of Pharmacy, China Medical University, Taichung 404, Taiwan;

E-Mails: yuchang@mail.cmu.edu.tw (Y.-C.C.); f91223033@ntu.edu.tw (H.-L.C.)

2 Department of Health and Nutrition Biotechnology, College of Health Science, Asia University, Taichung 412, Taiwan; E-Mail: cychao@asia,edu.tw

3 School of Pharmacy, College of Pharmacy, China Medical University, Taichung 404, Taiwan; E-Mail:wslin@mail.cmu.edu.tw

4 Department of Cosmeceutics, College of Pharmacy, China Medical University, Taichung 404, Taiwan; E-Mail: kuoping@mail.cmu.edu.tw

5 Tsuzuki Institute for Traditional Medicine, China Medical University, Taichung 404, Taiwan

* Authors to whom correspondence should be addressed;

E-Mails: gjhuang@mail.cmu.edu.tw (G.-J.H.); kuoyh@mail.cmu.edu.tw (Y.-H.K.);

Tel.: +886-4-220-533-66 (ext. 5508) (G.-J.H.); +886-4-220533-66 (ext. 5709) (Y.-H.K.); Fax: +886-4-220-716-93 (Y.-H.K.).

Received: 9 January 2013; in revised form: 5 February 2013 / Accepted: 10 February 2013 / Published: 26 February 2013

\begin{abstract}
Three new benzenoids, 3-isopropenyl-2-methoxy-6-methyl-4,5-methylenedioxyphenol (1), 2-hydroxy-4,4'-dimethoxy-3,3'-dimethyl-5,6,5',6'-bimethylenedioxybiphenyl (2), 4,4'-dihydroxy-3,3'-dimethoxy-2,2'-dimethyl-5,6,5',6'-bimethylenedioxybiphenyl (3), together with two known benzenoids, 2,3,6-trimethoxy-5-methylphenol (4) and 2,3-methylenedioxy4-methoxy-5-methylphenol (5), were isolated from Antrodia camphorata. Our results support that compounds 1-5 potently inhibited LPS (lipopolysaccharide)-induced nitric oxide (NO) production in a dose-dependent manner. The $\mathrm{IC}_{50}$ values of compounds $\mathbf{1}, \mathbf{3}$ and 5 were $1.8 \pm 0.2,18.8 \pm 0.6$ and $0.8 \pm 0.3 \mu \mathrm{g} / \mathrm{mL}$, respectively.
\end{abstract}

Keywords: Antrodia camphorata; polyporaceae; benzenoid; anti-inflammatory 


\section{Introduction}

Antrodia camphorata $\mathrm{Wu}$, Ryvarden and Chang (synonym: Ganoderma camphoratum, Antrodia cinnamomea, Taiwanofungus camphoratus) (Polyporaceae) is a parasitic fungus on the inner wall of the heartwood of Cinnamomun kanehiria Hay (Lauraceae). The fruiting bodies of A. camphorata are called "chang-chih" or "niu-chang-chih" in Taiwan. Traditionally, the fungus has been used for the treatment of food and drug intoxication, diarrhea, abdominal pain, hypertension and liver cancer [1]. The components of this fungus have shown activities of anti-inflammation [2-12], immune-modulation [13], anti-Helicobacter pylori [14], neuroprotection from A $\beta$ damage [15], anti-hepatitis-B virus [16,17] and anticancer [18-31]. Here, we present the result of chemical studies from a mixture of the fruiting body and mycelia of wood cultures of $A$. camphorata and three new benzenoids, 3-isopropenyl-2-methoxy-6-methyl-4,5-methylenedioxyphenol (1), 2-hydroxy-4,4'dimethoxy-3,3'-dimethyl-5,6,5',6'-bimethylenedioxybiphenyl (2), 4,4'-dihydroxy-3,3'-dimethoxy-2,2'dimethyl-5,6,5',6'-bimethylenedioxybiphenyl (3) together with two known benzenoids, 2,3,6-trimethoxy-5-methylphenol (4) and 2,3-methylenedioxy-4-methoxy-5-methylphenol (Figure 1), which were isolated and elucidated.

Figure 1. The chemical structures of compounds 1-5.

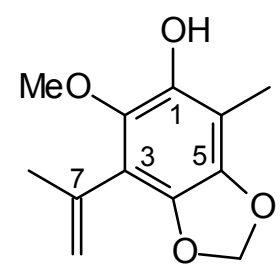

1

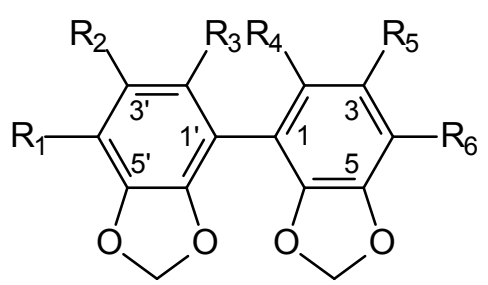

\begin{tabular}{|c|c|c|c|c|c|}
\hline $\mathrm{R}_{1}$ & $\mathrm{R}_{2}$ & $\mathrm{R}_{3}$ & $\mathrm{R}_{4}$ & $\mathrm{R}_{5}$ & $\mathrm{R}_{6}$ \\
\hline OMe & $\mathrm{Me}$ & प & $\mathrm{OH}$ & $\mathrm{Me}$ & OMe \\
\hline $\mathrm{OH}$ & OMe & $\mathrm{Me}$ & $\mathrm{Me}$ & OMe & $\mathrm{OH}$ \\
\hline 6 OMe & $\mathrm{Me}$ & $\mathrm{H}$ & $\mathrm{OM}$ & $\mathrm{Me}$ & $\mathrm{OH}$ \\
\hline
\end{tabular}<smiles>[R]c1cc(C)c(OC)c([R2])c1[R]</smiles>

\begin{tabular}{cccc}
$\mathrm{R}_{1}$ & $\mathrm{R}_{2}$ & $\mathrm{R}_{3}$ \\
\hline 4 & $\mathrm{OH}$ & $\mathrm{OMe}$ & $\mathrm{OMe}$ \\
5 & $-\mathrm{OCH}_{2} \mathrm{O}-$ & $\mathrm{OH}$
\end{tabular}

\section{Results and Discussion}

\subsection{Isolation and Structure Elucidation}

Extensive chromatographic purification of the EtOAc-soluble fraction (Fr. A) of the MeOH extract of $A$. camphorata afforded compounds $\mathbf{1}-\mathbf{5}$.

Compound 1 was isolated as colorless oil. Its molecular formula, $\mathrm{C}_{12} \mathrm{H}_{14} \mathrm{O}_{4}$, was determined by High Resolution Fast Atom Bombardment Mass Spectrometry (HR-FABMS) $\left([M+1]^{+}\right.$, $\mathrm{m} / \mathrm{z} 223.0963)$. The infrared (IR) spectral data showed the presence of the hydroxyl group $\left(3440 \mathrm{~cm}^{-1}\right)$ and the benzene ring $\left(1618,1510 \mathrm{~cm}^{-1}\right)$. The ${ }^{1} \mathrm{H}$ - and ${ }^{13} \mathrm{C}$-nuclear magnetic resonance (NMR) spectra (Table 1) of 1 showed the Heteronuclear Multiple-Quantum (HMQC) correlation, as follows: a $\mathrm{OCH}_{2} \mathrm{O}$ moiety $\left[\delta_{\mathrm{H}} 5.93(\mathrm{~s}), \delta_{\mathrm{C}} 101.7\right]$, a Me group [ $\left.\delta_{\mathrm{H}} 2.27(\mathrm{~s}), \delta_{\mathrm{C}} 13.3\right]$ and a $\mathrm{MeO}$ group [ $\delta_{\mathrm{H}} 3.94(\mathrm{~s})$, $\left.\delta_{\mathrm{C}} 60.4\right]$ on the phenol. The presence of an isopropenyl group was revealed by a Me group [ $\delta_{\mathrm{H}} 1.99(\mathrm{~s})$, $\delta_{\mathrm{C}}$ 23.5], two olefinic protons of $\mathrm{CH}_{2}\left[\delta_{\mathrm{H}} 5.24\right.$ (br s), 5.36 (br s), $\delta_{\mathrm{C}} 121.0$ ] and a quaternary C-atom $\left[\delta_{\mathrm{C}} 127.2(\mathrm{C}-7)\right]$. On the basis of HMBC (Figure 2), cross-peaks $\left[\delta_{\mathrm{H}} 5.93\left(\mathrm{OCH}_{2} \mathrm{O}\right)\right.$ coupled to $\delta_{\mathrm{C}}$ 
$133.0(\mathrm{C}-5)$ and $136.0(\mathrm{C}-4) ; \delta_{\mathrm{H}} 2.27(\mathrm{Me})$ correlated to $\delta_{\mathrm{C}} 110.0(\mathrm{C}-6), 132.0(\mathrm{C}-1)$ and $133.0(\mathrm{C}-5)$; $\delta_{\mathrm{H}} 4.64(\mathrm{OH})$ coupled to $\delta_{\mathrm{C}} 132.0(\mathrm{C}-1) ; \delta_{\mathrm{H}} 3.94(\mathrm{MeO})$ coupled to $\delta_{\mathrm{C}} 138.5(\mathrm{C}-2) ; \delta_{\mathrm{H}} 1.99(\mathrm{Me}-7)$ coupled to $\delta_{\mathrm{C}} 97.1(\mathrm{C}-3)$ ] and a combination with the Nuclear Overhauser Effect Spectroscopy (NOESY) experiment (Figure 2) [MeO $\left(\delta_{\mathrm{H}} 3.94\right)$ correlation with isopropenyl group $\left(\delta_{\mathrm{H}} 1.99,5.24\right.$, 5.36)] corroborated the locations of the functional groups on the benzene ring. On the basis of the ${ }^{1} \mathrm{H}$ - and ${ }^{13} \mathrm{C}-\mathrm{NMR}$ (Table 1), NOESY (Figure 2), Distortionless Enhancement by Polarization Transfer (DEPT), HMQC and Heteronuclear Multiple Bond Correlation (HMBC) (Figure 2) experiments, 1 was characterized as 3-isopropenyl-2-methoxy-6-methyl-4,5-methylenedioxyphenol.

Table 1. ${ }^{1} \mathrm{H}$ - and ${ }^{13} \mathrm{C}$-nuclear magnetic resonance (NMR) data $\left(\mathrm{CDCl}_{3}, 500\right.$ and $125 \mathrm{MHz}$, resp.) of Compounds 1-3. Chemical shifts $\delta$ in ppm rel. to TMS, $J$ in Hz. For atom numbering, see the Formulae.

\begin{tabular}{|c|c|c|c|c|c|c|}
\hline \multirow{2}{*}{ Position } & \multicolumn{2}{|c|}{1} & \multicolumn{2}{|c|}{2} & \multicolumn{2}{|c|}{3} \\
\hline & $\delta_{H}$ & $\boldsymbol{\delta}_{\mathrm{C}}$ & $\delta_{H}$ & $\boldsymbol{\delta}_{\mathrm{C}}$ & $\delta_{H}$ & $\boldsymbol{\delta}_{\mathrm{C}}$ \\
\hline 1 & - & 132.0 & - & 129.3 & - & 123.7 \\
\hline 2 & - & 138.5 & - & 135.6 & - & 114.6 \\
\hline 3 & - & 97.1 & - & 116.8 & - & 136.0 \\
\hline 4 & - & 136.0 & - & 135.0 & - & 133.2 \\
\hline 5 & - & 133.0 & - & $136.0^{\dagger}$ & - & $138.9^{*}$ \\
\hline 6 & - & 110.0 & - & $133.4^{\dagger}$ & - & $133.3^{*}$ \\
\hline 7 & - & 127.2 & - & - & - & - \\
\hline $\mathrm{Me}-2$ & - & - & - & - & $1.82(\mathrm{~s})$ & 12.7 \\
\hline $\mathrm{Me}-3$ & - & - & $1.97(\mathrm{~s})$ & 9.4 & - & - \\
\hline Me-6 & $2.27(\mathrm{~s})$ & 13.3 & - & - & - & - \\
\hline $\mathrm{MeO}-2$ & $3.94(\mathrm{~s})$ & 60.4 & - & - & - & - \\
\hline $\mathrm{MeO}-3$ & - & - & - & - & $3.88(\mathrm{~s})$ & 60.1 \\
\hline $\mathrm{MeO}-4$ & - & - & $3.88(\mathrm{~s})$ & 60.1 & - & - \\
\hline $\mathrm{Me}-7$ & $1.99(\mathrm{~s})$ & 23.5 & - & - & - & - \\
\hline $\mathrm{CH}_{2}-7$ & $\begin{array}{l}5.24 \text { (br s) } \\
5.36 \text { (br s) }\end{array}$ & 121.0 & - & - & - & - \\
\hline $4-\mathrm{OCH}_{2} \mathrm{O}-5$ & $5.93(\mathrm{~s})$ & 101.7 & - & - & - & - \\
\hline $5-\mathrm{OCH}_{2} \mathrm{O}-6$ & - & - & $5.96(\mathrm{~s})$ & 101.8 & $5.99(\mathrm{~s})$ & 101.7 \\
\hline $1^{\prime}$ & - & - & - & 136.1 & - & 123.7 \\
\hline $2^{\prime}$ & - & - & $5.94(\mathrm{~s})$ & 109.5 & - & 114.6 \\
\hline $3^{\prime}$ & - & - & - & 124.1 & - & 136.0 \\
\hline $4^{\prime}$ & - & - & - & 137.4 & - & 133.2 \\
\hline $5^{\prime}$ & - & - & - & 138.6 & - & 138.9 \\
\hline $6^{\prime}$ & - & - & - & 134.4 & - & 133.3 \\
\hline Me-2' & - & - & - & - & $1.82(\mathrm{~s})$ & 12.7 \\
\hline Me-3' & - & - & $2.03(\mathrm{~s})$ & 15.8 & - & - \\
\hline $\mathrm{MeO}-3^{\prime}$ & - & - & - & - & $3.88(\mathrm{~s})$ & 60.1 \\
\hline $\mathrm{MeO}-4^{\prime}$ & - & - & $3.87(\mathrm{~s})$ & 59.7 & - & - \\
\hline $5^{\prime}-\mathrm{OCH}_{2} \mathrm{O}-6^{\prime}$ & - & - & $5.98(\mathrm{~s})$ & 101.7 & $5.99(\mathrm{~s})$ & 101.7 \\
\hline $\mathrm{OH}$ & $4.64(\mathrm{~s})$ & - & - & - & $4.56(\mathrm{~s})$ & - \\
\hline
\end{tabular}


Figure 2. Nuclear Overhauser Effect Spectroscopy (NOESY) contacts (a) and key Heteronuclear Multiple Bond Correlation (HMBC) connectivities (b) of compound 1.

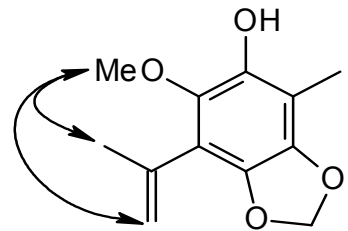

(a)

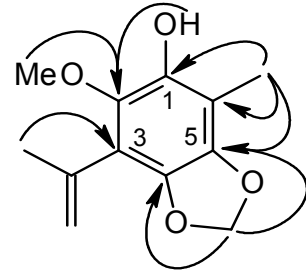

(b)

Compound 2 was isolated as an amorphous solid. Its molecular formula, $\mathrm{C}_{18} \mathrm{H}_{18} \mathrm{O}_{7}$, was determined by HR-FABMS $\left([\mathrm{M}+1]^{+}, m / z\right.$ 347.1128). The presence of phenolic moiety was revealed by IR spectral data $\left(3481,1615,1512 \mathrm{~cm}^{-1}\right)$. The above data combined with the NMR data (Table 1) revealed 2 to be a biphenyl compound. The ${ }^{1} \mathrm{H}-\mathrm{NMR}$ spectrum (Table 1) of 2 showed two $\mathrm{OCH}_{2} \mathrm{O}$ groups $\left[\delta_{\mathrm{H}} 5.96\left(\mathrm{~s}, 5-\mathrm{OCH}_{2} \mathrm{O}-6\right), 5.98\left(\mathrm{~s}, 5^{\prime}-\mathrm{OCH}_{2} \mathrm{O}-6^{\prime}\right)\right]$, two $\mathrm{MeO}$ groups $\left[\delta_{\mathrm{H}} 3.87\right.$ (s, MeO-4'), $3.88(\mathrm{~s}, \mathrm{MeO}-4)]$, two Me groups [ $\delta_{\mathrm{H}} 1.97(\mathrm{~s}, \mathrm{Me}-3), 2.03$ (s, Me-3')] and a single aromatic proton $\left[\delta_{\mathrm{H}} 5.94\left(\mathrm{~s}, \mathrm{H}-2^{\prime}\right)\right]$. The ${ }^{13} \mathrm{C}-\mathrm{NMR}$ (Table 1) and DEPT spectra showed that $\mathbf{2}$ had a total of $18 \mathrm{C}$-atoms, accounting for two $\mathrm{Me}$ [ $\left.\delta_{\mathrm{C}} 9.42(\mathrm{Me}-3), 15.8\left(\mathrm{Me}-3^{\prime}\right)\right]$, two $\mathrm{MeO}$ [ $\left.\delta_{\mathrm{C}} 59.7\left(\mathrm{MeO}-4{ }^{\prime}\right), 60.1(\mathrm{MeO}-4)\right]$, two $\mathrm{OCH}_{2} \mathrm{O}\left[\delta_{\mathrm{C}} 101.7\left(5^{\prime}-\mathrm{OCH}_{2} \mathrm{O}-6\right.\right.$ '), $\left.101.8\left(5-\mathrm{OCH}_{2} \mathrm{O}-6\right)\right]$, one aromatic $\mathrm{CH}\left[\delta_{\mathrm{C}} 109.5\left(\mathrm{C}-2^{\prime}\right)\right]$ and 11 aromatic quaternary C-atoms [ $\delta_{\mathrm{C}} 116.8$ (C-3), 124.1 (C-3'), 129.3 (C-1), 133.4 (C-6), 134.4 (C-6'), 135.0 (C-4), 135.6 (C-2), 136.0 (C-5), 136.1 (C-1'), 137.4 (C-4'), 138.6 (C-5')]. These data also indicated a biphenyl skeleton. Assignment of chemical shifts of all protonated $\mathrm{C}$-atoms and their associated $\mathrm{H}$-atoms in the molecule can be finished according to HMQC data. On the basis of HMBC (Figure 3), cross-peaks of MeO-4 with C-4, of MeO-4' with C-4', of Me-3 with C-2, C-3 and C-4, of Me-3' with C-2', C-3' and C-4', of 5-OCH${ }_{2} \mathrm{O}-6$ with C-5 and C-6, of 5'-OCH${ }_{2} \mathrm{O}-6$ ' with C-5' and C-6' and of $\mathrm{H}-2$ ' with $\mathrm{C}-1$ ', C-4' and $\mathrm{C}-6$ ', the remaining $\mathrm{C}$-atoms of the aromatic ring, $\mathrm{C}-1$, were assigned. The NOESY experiment (Figure 2) showing Me-3 correlated with MeO-4 and Me-3' correlated with $\mathrm{H}-2^{\prime}$ and $\mathrm{MeO}-4$ ' further supported the substitution pattern. According the above evidence, compound 2 can be assigned as structures 2 or $\mathbf{6}$ (Figure 1). The statistical calculation from a text book [32] suggested that the difference of ${ }^{13} \mathrm{C}$ chemical shift between $\mathrm{C}-2$ and $\mathrm{C}-4$ is slight for structure $\mathbf{2}$ and larger for structure $\mathbf{6}$. Therefore, we assigned the compound $\mathbf{2}$, as structure $\mathbf{2}$ is more reasonable, and structure 6 will be excluded. On the basis of the ${ }^{1} \mathrm{H}$ - and ${ }^{13} \mathrm{C}$-NMR (Table 1), NOESY (Figure 2), DEPT, HMQC and HMBC (Figure 3) experiments and comparison of ${ }^{13} \mathrm{C}-\mathrm{NMR}$ values between $\mathrm{C}-2$ and $\mathrm{C}-4$, compound $\mathbf{2}$ was characterized as 2-hydroxy-4,4'-dimethoxy-3,3'-dimethyl-5,6,5',6'-bimethylenedioxybiphenyl (Figure 3).

Figure 3. NOESY contacts (a) and key HMBC connectivities (b) of compound 2.

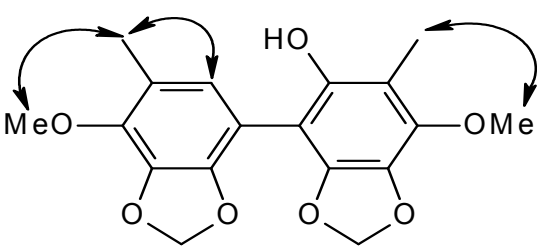

(a)

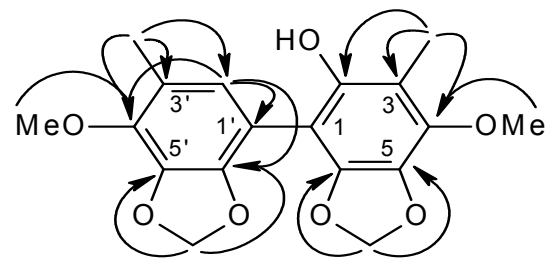

(b) 
Compound 3 was isolated as an amorphous solid. Its molecular formula, $\mathrm{C}_{18} \mathrm{H}_{18} \mathrm{O}_{8}$, was determined by HR-FABMS $\left([\mathrm{M}+1]^{+}, \mathrm{m} / z\right.$ 363.1076). The presence of phenolic moiety was revealed by IR spectral data $\left(3421,1605,1508 \mathrm{~cm}^{-1}\right)$. According to the molecular formula, IR spectrum combined with nine ${ }^{13} \mathrm{C}$-NMR signals indicated that compound $\mathbf{3}$ is a symmetrical biphenolic derivative. These data with the NMR data (Table 1) suggest a biphenyl compound. The ${ }^{1} \mathrm{H}-\mathrm{NMR}$ spectrum (Table 1) of 3 showed a $\mathrm{OCH}_{2} \mathrm{O}$ group $\left[\delta_{\mathrm{H}} 5.99\left(\mathrm{~s}, 5-\mathrm{OCH}_{2} \mathrm{O}-6\right)\right]$, a $\mathrm{MeO}$ group [ $\delta_{\mathrm{H}} 3.88(\mathrm{~s}, \mathrm{MeO}-3)$ ], a Me group $\left[\delta_{\mathrm{H}} 1.82(\mathrm{~s}, \mathrm{Me}-2)\right]$ and a hydroxy group $\left[\delta_{\mathrm{H}} 4.56(\mathrm{~s}, \mathrm{HO}-4)\right]$. The ${ }^{13} \mathrm{C}-\mathrm{NMR}$ (Table 1$)$ and DEPT spectra of 3 showed nine signals, accounting for a $\mathrm{Me}$ [ $\left.\delta_{\mathrm{C}} 12.7(\mathrm{Me}-2)\right]$, a $\mathrm{MeO}$ [ $\left.\delta_{\mathrm{C}} 60.1(\mathrm{MeO}-3)\right]$, a $\mathrm{OCH}_{2} \mathrm{O}\left[\delta_{\mathrm{C}} 101.7\left(5-\mathrm{OCH}_{2} \mathrm{O}-6\right)\right]$ and six aromatic quaternary C-atoms $\left(\delta_{\mathrm{C}} 114.6(\mathrm{C}-2), 123.7(\mathrm{C}-1)\right.$, 133.2 (C-4), 133.3 (C-6), 136.0 (C-3), 138.9 (C-5). Because HR-FABMS showed that the molecular formula is $\mathrm{C}_{18} \mathrm{H}_{18} \mathrm{O}_{8}, 3$ was suggested to be a symmetrical biphenolic compound. The HMBC data (Figure 4) showed that the $\mathrm{H}$-atom signal of Me-2 correlated to the $\mathrm{C}$-atom signals of C-1, C-2 and C-3 and the $\mathrm{H}$-atom signals of $\mathrm{MeO}-3$ and $\mathrm{HO}-4$ correlated to the $\mathrm{C}$-atom signal of $\mathrm{C}-3$, suggesting that $\mathrm{OCH}_{2} \mathrm{O}$ group was positioned at $\mathrm{C}-5$ and $\mathrm{C}-6$. On the basis of the ${ }^{1} \mathrm{H}$ - and ${ }^{13} \mathrm{C}-\mathrm{NMR}$ (Table 1), NOESY (Figure 4), DEPT, HMQC and HMBC (Figure 4) experiments, 3 was characterized as 4,4'-dihydroxy-3,3'-dimethoxy-2,2'-dimethyl-5,6,5',6'-bimethylenedioxybiphenyl (Figure 4).

The known isolates, 2,3,6-trimethoxy-5-methylphenol (4) [33] and 2,3-methylenedioxy-4-methoxy5-methylphenol (5) [33], were readily identified by comparison of physical and spectroscopic data (UV, IR, ${ }^{1} \mathrm{H}$ NMR and mass spectrometry data) with values found in the literature.

Figure 4. NOESY contacts (a) and key HMBC connectivities (b) of compound 3.

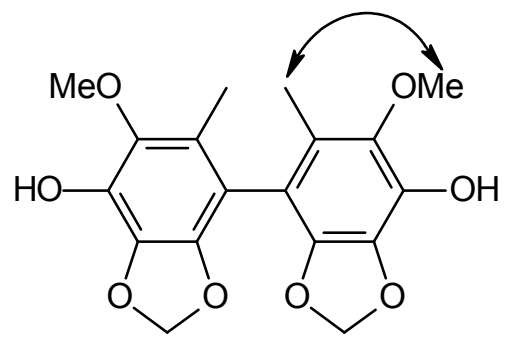

(a)

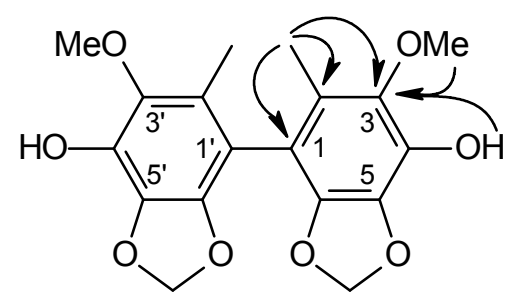

(b)

\subsection{Anti-Inflammatory Activities}

Compounds 1-5 were evaluated for anti-inflammatory activities and exhibited the potential inhibition against LPS (lipopolysaccharide)-induced NO in a dose-dependent manner (Table 2). The $\mathrm{IC}_{50}$ values of compounds $\mathbf{1}, \mathbf{3}$ and $\mathbf{5}$ were $1.8 \pm 0.2,18.8 \pm 0.6$ and $0.8 \pm 0.3 \mu \mathrm{g} / \mathrm{mL}$, respectively (Table 2 ).

Compounds 5 is very potent $\left(\mathrm{IC}_{50}=0.8\right)$ for the inhibition of NO production. We will study the anti-inflammatory activities of compound 5 further. 
Table 2. Cell viability and effect of compounds 1-5 on LPS-induced NO production in macrophages ${ }^{\text {a }}$.

\begin{tabular}{|c|c|c|c|c|}
\hline Compound & Dose $(\mu \mathrm{g} / \mathrm{mL})$ & $\begin{array}{l}\text { Cell viability } \\
\text { (\% of control) }\end{array}$ & NO level $(\mu \mathrm{M})$ & $\mathrm{IC}_{50}(\mu \mathrm{g} / \mathrm{mL})$ \\
\hline control & $(-)$ & $96.4 \pm 4.3$ & $2.5 \pm 0.2$ & \\
\hline LPS & $(+)$ & $97.0 \pm 0.8$ & 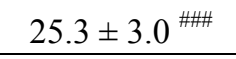 & \\
\hline \multirow[t]{5}{*}{1} & 0.312 & $92.0 \pm 3.3$ & $14.5 \pm 2.2^{* *}$ & $1.8 \pm 0.2$ \\
\hline & 0.625 & $91.0 \pm 3.7$ & $14.1 \pm 1.5^{* *}$ & \\
\hline & 1.25 & $90.4 \pm 2.4$ & $13.0 \pm 1.5^{* * *}$ & \\
\hline & 2.5 & $87.3 \pm 2.3$ & $12.0 \pm 1.7^{* * *}$ & \\
\hline & 5 & $65.5 \pm 1.7$ & $(-)$ & \\
\hline \multirow[t]{5}{*}{2} & 0.312 & $98.0 \pm 1.5$ & $16.4 \pm 2.4^{* *}$ & \\
\hline & 0.625 & $96.6 \pm 7.6$ & $16.1 \pm 1.3^{* *}$ & \\
\hline & 1.25 & $96.6 \pm 2.2$ & $15.7 \pm 2.0^{* *}$ & \\
\hline & 2.5 & $92.7 \pm 1.3$ & $15.5 \pm 1.9^{* *}$ & \\
\hline & 5 & $71.4 \pm 2.2$ & $(-)$ & \\
\hline \multirow[t]{5}{*}{3} & 3.12 & $95.1 \pm 2.9$ & $13.7 \pm 0.1^{* * *}$ & $18.8 \pm 0.6$ \\
\hline & 6.25 & $93.1 \pm 2.7$ & $13.4 \pm 0.4^{* * *}$ & \\
\hline & 12.5 & $93.0 \pm 2.6$ & $13.2 \pm 0.1^{* * *}$ & \\
\hline & 25 & $91.0 \pm 7.7$ & $12.1 \pm 0.6^{* * *}$ & \\
\hline & 50 & $64.8 \pm 2.2$ & $(-)$ & \\
\hline \multirow[t]{5}{*}{4} & 0.312 & $97.0 \pm 1.1$ & $20.6 \pm 1.2^{*}$ & \\
\hline & 0.625 & $96.2 \pm 2.2$ & $19.4 \pm 2.0^{*}$ & \\
\hline & 1.25 & $95.0 \pm 2.1$ & $18.3 \pm 0.3^{* *}$ & \\
\hline & 2.5 & $94.6 \pm 1.6$ & $13.6 \pm 0.6^{* * *}$ & \\
\hline & 5 & $69.3 \pm 2.1$ & $(-)$ & \\
\hline \multirow[t]{5}{*}{5} & 0.312 & $93.8 \pm 2.9$ & $15.2 \pm 1.4^{* *}$ & $0.8 \pm 0.3$ \\
\hline & 0.625 & $88.5 \pm 1.5$ & $12.8 \pm 1.9^{* * *}$ & \\
\hline & 1.25 & $85.0 \pm 2.9$ & $12.1 \pm 1.6^{* * *}$ & \\
\hline & 2.5 & $83.8 \pm 1.9$ & $10.4 \pm 1.3^{* * *}$ & \\
\hline & 5 & $82.4 \pm 2.7$ & $10.0 \pm 2.2^{* * *}$ & \\
\hline \multirow[t]{2}{*}{ Indomethacin } & 25 & $96.2 \pm 1.1$ & $19.2 \pm 0.6^{*}$ & \\
\hline & 50 & $94.8 \pm 1.3$ & $14.3 \pm 0.8^{* *}$ & \\
\hline
\end{tabular}

${ }^{a}$ The data were presented as the mean \pm SD for three different experiments performed in triplicate.

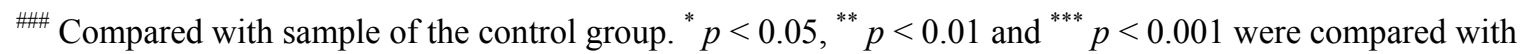
the LPS-alone group.

\section{Experimental Section}

\subsection{General}

Column chromatography (CC): silica gel 60 (Merck 70-230 mesh, 230-400 mesh, ASTM). Prep. HPLC: (LDC Analytical-III system; column: LiChrosorb Si 60, $7 \mu \mathrm{m}, 250 \times 10 \mathrm{~mm}$ ). UV: Hitachi $\mathrm{S}-3200$ spectrometer; $\lambda_{\max }(\log \varepsilon)$ in $\mathrm{nm}$. IR spectra: Perkin-Elmer $983 \mathrm{G}$ spectrophotometer; $v$ in $\mathrm{cm}^{-1}$. ${ }^{1} \mathrm{H}-,{ }^{13} \mathrm{C}$ - and 2D-NMR spectra: Bruker DMX-500 spectrometer; $\delta$ in ppm rel. to TMS, $J$ in $\mathrm{Hz}$. HR-FABMS: JEOL $S X-102 A$ spectrometer; $\mathrm{m} / z$. 


\subsection{Plant Material}

The solid cultural fruiting bodies of $A$. camphorata were identified and provided by Po-Zone Biotechnology Development, Taipei, Taiwan. A voucher specimen was deposited at Po-Zone Biotechnology Development Co. Ltd.

\subsection{Extraction and Isolation}

The fruiting bodies of wood culture $A$. camphorata $(500 \mathrm{~g})$ were extracted with $\mathrm{MeOH}(4 \mathrm{~L})$ by maceration at room temperature $(7$ days $\times 3)$. After removal of $\mathrm{MeOH}$ under vacuum, the extract was partitioned into EtOAc (Fr. A, $113 \mathrm{~g}$ ), $n$-BuOH (Fr. B, $15 \mathrm{~g}$ ) and $\mathrm{H}_{2} \mathrm{O}$-soluble (Fr. C, $27 \mathrm{~g}$ ) fractions. The EtOAc fraction (Fr. A, $113 \mathrm{~g})$ was subjected to CC $(10 \times 70 \mathrm{~cm}$, silica gel, 230-400 mesh) using n-hexane, EtOAc and $\mathrm{MeOH}$ of increasing polarity as eluent to obtain 11 fractions: Frs. A1-A18. Fr. A4 (11 g, $n$-hexane/EtOAc 8:2) was subjected to HPLC $\left(\mathrm{CH}_{2} \mathrm{Cl}_{2} / \mathrm{EtOAc} 9: 1\right)$ to yield 4 (11.9 mg) and 5 (73.2 mg). Fr. A5 (30 g, $n$-hexane/EtOAc 7:3) was subjected to HPLC $\left(\mathrm{CH}_{2} \mathrm{Cl}_{2} /\right.$ EtOAc 9:1) to yield $\mathbf{1}(4.2 \mathrm{mg}), \mathbf{2}(7.3 \mathrm{mg})$ and $\mathbf{3}(5.1 \mathrm{mg})$.

\subsection{3-Isopropenyl-2-methoxy-6-methyl-4,5-methylenedioxyphenol (1)}

Colorless oil. UV (MeOH): 280 (3.92). IR (neat): 3440, 1618, 1510, 1470, 1230, 1061, 1026. ${ }^{1} \mathrm{H}$ - and ${ }^{13} \mathrm{C}-\mathrm{NMR}$ : see Table 1. HR-FABMS $m / z$ : $223.0963[\mathrm{M}+1]^{+}\left(\mathrm{C}_{12} \mathrm{H}_{15} \mathrm{O}_{4}{ }^{+}\right.$, calc. 223.0970).

\subsection{2-Hydroxy-4,4'-dimethoxy-3,3'-dimethyl-5, 6, 5',6'-bimethylenedioxybiphenyl (2)}

Amorphous solid. UV (MeOH): 276 (3.86). IR (KBr): 3481, 1615, 1512, 1468, 1240, 1155. ${ }^{1} \mathrm{H}$ - and ${ }^{13} \mathrm{C}$-NMR: see Table 1. HR-FABMS $m / z$ : $347.1128[\mathrm{M}+1]^{+}\left(\mathrm{C}_{18} \mathrm{H}_{19} \mathrm{O}_{7}{ }^{+}\right.$, calc. 347.1131$)$.

\subsection{4,4'-Dihydroxy-3,3'-dimethoxy-2,2'-dimethyl-5,6,5',6'-bimethylenedioxybiphenyl (3)}

Amorphous solid. UV (MeOH): 270 (3.74). IR (KBr): 3421, 1605, 1508, 1472, 1233, 1130, 1089. ${ }^{1} \mathrm{H}$ - and ${ }^{13} \mathrm{C}-\mathrm{NMR}$ : see Table 1. HR-FABMS m/z: $363.1076[\mathrm{M}+1]^{+}\left(\mathrm{C}_{18} \mathrm{H}_{19} \mathrm{O}_{8}{ }^{+}\right.$, calc. 363.1080$)$.

\subsection{Chemicals}

LPS (endotoxin from Escherichia coli, serotype 0127:B8), Carr (type IV), indomethacin, MTT (3-[4,5-dimethylthiazol-2-yl]-2,5-diphenyltetrazolium bromide) and other chemicals were purchased from Sigma-Aldrich Chemical Co. (St. Louis, MO, USA).

\subsection{Cell Culture}

A murine macrophage cell line, RAW264.7 (BCRC No. 60001), was purchased from the Bioresources Collection and Research Center (BCRC, Hsinchu, Taiwan) of the Food Industry Research and Development Institute (Hsinchu, Taiwan). Cells were cultured in plastic dishes containing Dulbecco's Modified Eagle Medium (DMEM, Sigma, St. Louis, MO, USA) supplemented with $10 \%$ fetal bovine serum (FBS, Sigma) in a $\mathrm{CO}_{2}$ incubator $\left(5 \% \mathrm{CO}_{2}\right.$ in air) at $37{ }^{\circ} \mathrm{C}$ and 
subcultured every 3 days at a dilution of $1: 5$ using $0.05 \%$ trypsin- $0.02 \%$ EDTA in $\mathrm{Ca}^{2+}-\mathrm{Mg}^{2+}$-free phosphate-buffered saline (DPBS).

\subsection{Cell Viability}

Cells $\left(2 \times 10^{5}\right)$ were cultured in 96-well plate containing DMEM supplemented with 10\% FBS for 1 day to become nearly confluent. Then, cells were cultured with compounds $\mathbf{1}-\mathbf{5}$ in the presence of $100 \mathrm{ng} / \mathrm{mL}$ LPS (lipopolysaccharide) (Eschericha coli 026:B6; Sigma-Aldrich, St. Louis, Mo) for $24 \mathrm{~h}$. After that, the cells were washed twice with DPBS and incubated with $100 \mu \mathrm{L}$ of $0.5 \mathrm{mg} / \mathrm{mL}$ MTT for $2 \mathrm{~h}$ at $37{ }^{\circ} \mathrm{C}$ testing for cell viability. The medium was then discarded, and $100 \mu \mathrm{L}$ dimethyl sulfoxide (DMSO) was added. After 30-min incubation, absorbance at $570 \mathrm{~nm}$ was read using a microplate reader (Molecular Devices, Sunnyvale, CA, USA).

\subsection{Measurement of Nitric Oxide/Nitrite}

NO production was indirectly assessed by measuring the nitrite levels in the cultured media and serum determined by a colorimetric method based on the Griess reaction. The cells were incubated with different concentrations of samples in the presence of LPS $(100 \mathrm{ng} / \mathrm{mL})$ at $37^{\circ} \mathrm{C}$ for $24 \mathrm{~h}$. Then, cells were dispensed into 96-well plates, and $100 \mu \mathrm{L}$ of each supernatant was mixed with the same volume of Griess reagent ( $1 \%$ sulfanilamide, $0.1 \%$ naphthyl ethylenediamine dihydrochloride and 5\% phosphoric acid) and incubated at room temperature for $10 \mathrm{~min}$; the absorbance was measured at $540 \mathrm{~nm}$ with a Micro-Reader (Molecular Devices).

\subsection{Statistical Analysis}

$\mathrm{IC}_{50}$ values were estimated using a non-linear regression algorithm (Sigma Plot 8.0; SPSS Inc., Chicago, IL, USA). Statistical evaluation was carried out by one-way analysis of variance (ANOVA, followed by Scheffe's multiple range tests).

\section{Conclusions}

3-Isopropenyl-2-methoxy-6-methyl-4,5-methylenedioxyphenol (1), 2-hydroxy-4,4'-dimethoxy-3,3'dimethyl-5,6,5',6'-bimethylenedioxybiphenyl (2) and 4,4'-dihydroxy-3,3'-dimethoxy-2,2'-dimethyl5,6,5',6'-bimethylenedioxybiphenyl (3) are new compounds from A. camphorata. Compounds $\mathbf{1}, \mathbf{3}$ and 5 displayed a significant concentration-dependent inhibition of $\mathrm{NO}$ production with $\mathrm{IC}_{50}$ values $1.8 \pm 0.2,18.8 \pm 0.6$ and $0.8 \pm 0.3 \mu \mathrm{g} / \mathrm{mL}$, respectively.

\section{Acknowledgments}

This work was kindly supported by a grant from the China Medical University (CMU100-S-10), in part by the Taiwan Department of Heath Clinical Trial and Research Center of Excellence (DDH 102-TD-B-111-004). 


\section{Conflict of Interest}

The authors declare no conflict of interest.

\section{References}

1. Tsai, Z.T.; Liaw, S.L. The Use and the Effect of Ganoderma; Sang-Yun Press: Taichung, Taiwan, 1982; p. 116.

2. Shen, Y.C.; Chou, C.J.; Wang, Y.H.; Chen, C.F.; Chou, Y.C.; Lu, M.K. Anti-inflammatory activity of the extracts from mycelia of Antrodia camphorata cultured with water-soluble fractions from five different Cinnamomum species. FEMS Microbiol. Lett. 2004, 231, 137-143.

3. Shen, Y.C.; Wang, Y.H.; Chou, Y.C.; Chen, C.F.; Lin, L.C.; Chang, T.T.; Tien, J.H.; Chou, C.J. Evaluation of the anti-inflammatory activity of zhankuic acids isolated from the fruiting bodies of Antrodia camphorata. Planta Med. 2004, 70, 310-314.

4. Cheng, J.J.; Yang, C.J.; Cheng, C.H.; Wang, Y.T.; Huang, N.K.; Lu, M.K. Characterization and functional study of Antrodia camphorata lipopolysaccharide. J. Agric. Food Chem. 2005, 53, 469-474.

5. Chen, J.J.; Lin, W.J.; Liao, C.H.; Shieh, P.C. Anti-inflammatory benzenoids from Antrodia camphorata. J. Nat. Prod. 2007, 70, 989-992.

6. Chien, S.C.; Chen, M.L.; Kuo, H.T.; Tsai, Y.C.; Lin, B.F.; Kuo, Y.H. Anti-inflammatory activities of new succinic and maleic derivatives from the fruiting body of Antrodia camphorata. J. Agric. Food Chem. 2008, 56, 7017-7022.

7. Yang, S.S.; Wang, G.J.; Wang, S.Y.; Lin, Y.Y.; Kuo, Y.H.; Lee, T.H. New constituents with iNOS inhibitory activity from mycelium of Antrodia camphorata. Planta Med. 2009, 75, 512-516.

8. Wu, S.J.; Leu, Y.L.; Chen, C.H.; Chao, C.H.; Shen, D.Y.; Chan, H.H.; Lee, E.J.; Wu, T.S.; Wang, Y.H.; Shen, Y.C.; et al. Camphoratins A-J, potent cytotoxic and anti-inflammatory triterpenoids from the fruiting body of Taiwanofungus camphoratus. J. Nat. Prod. 2010, 73, $1756-1762$.

9. Huang, G.J.; Huang, S.S.; Lin, S.S.; Shao, Y.Y.; Chen, C.C.; Hou, W.C.; Kuo, Y.H. Analgesic effects and the mechanisms of anti-inflammation of ergostatrien-3 $\beta$-ol from Antrodia camphorata submerged whole broth in mice J. Agric. Food Chem. 2010, 58, 7445-7452.

10. Chen, Y.C.; Liu, Y.L.; Li, F.Y.; Chang, C.I.; Wang, S.Y.; Lee, K.Y.; Li, S.L.; Chen, Y.P.; Jinn, T.R.; Tzen, J.T.C. Antcin A, a steroid-like compound from Antrodia camphorata, exerts anti-inflammatory effect via mimicking glucocorticoids. Acta Pharmacol. Sin. 2011, 32, 904-911.

11. Chung, T.Y.; Li, F.Y.; Chang, C.I.; Jinn, T.R.; Tzen, J.T.C. Inhibition of $\mathrm{Na}^{+} / \mathrm{K}^{+}$-ATPase by antcins, unique steroid-like compounds in Antrodia camphorate. Am. J. Chin. Med. 2012, 40, 953-965.

12. Huang, G.J.; Deng, J.S.; Huang, S.S.; Shao, Y.Y.; Chen, C.C.; Kuo, Y.H. Protective effect of antrosterol from Antrodia camphorata submerged whole broth against carbon tetrachloride-induced acute liver injury in mice. Food Chem. 2012, 132, 709-716.

13. Shen, Y.C.; Chen, C.F.; Wang, Y.H.; Chang, T.T.; Chou, C.J. Evaluation of the immuno-modulating activity of some active principles isolated from the fruiting bodies of Antrodia camphorata. Chin. Pharm. J. 2003, 55, 313-318. 
14. Geethangili, M.; Fang, S.H.; Lai, C.H.; Rao, Y.K.; Lien, H.M.; Tzeng, Y.M. Inhibitory effect of Antrodia camphorata constituents on the Helicobacter pylori-associated gastric inflammation. Food Chem. 2010, 119, 149-153.

15. Chen, C.C.; Shiao, Y.J.; Lin, R.D.; Shao, Y.Y.; Lai, M.N.; Lin, C.C.; Ng, L.T.; Kuo, Y.H. Neuroprotective diterpenes from the fruiting body of Antrodia camphorata. J. Nat. Prod. 2006, 69, 689-691.

16. Lee, I.H.; Huang, R.L.; Chen, C.T.; Chen, H.C.; Hsu, W.C.; Lu, M.K. Antrodia camphorata polysaccharides exhibit anti-hepatitis B virus effects. FEMS Microbiol. Lett. 2002, 209, 63-67.

17. Huang, R.L.; Huang, Q.; Chen, C.F.; Chang, T.T.; Chou, C.J. Anti-viral effects of active compounds from Antrodia camphorata on wild-type and lamivudine-resistant mutant HBV. Chin. Pharm. J. 2003, 55, 371-379.

18. Nakamura, N.; Hirakawa, A.; Gao, J.J.; Kakuda, H.; Shiro, M.; Komatsu, Y.; Sheu, C.C.; Hattori, M. Five new maleic and succinic acid derivatives from the mycelium of Antrodia camphorata and their cytotoxic effects on LLC tumor cell line J. Nat. Prod. 2004, 67, 46-48.

19. Liu, J.J.; Huang, T.S.; Hsu, M.L.; Chen, C.C.; Lin, W.S.; Lu, F.J.; Chang, W.H. Antitumor effects of the partially purified polysaccharides from Antrodia camphorata and the mechanism of its action. Toxicol. Appl. Pharmacol. 2004, 201, 186-193.

20. Lee, T.H.; Lee, C.K.; Tsou, W.L.; Liu, S.Y.; Kuo, M.T.; Wen, W.C. A new cytotoxic agent from solid-state fermented mycelium of Antrodia camphorata. Planta Med. 2007, 73, 1412-1415.

21. Yeh, C.T.; Rao, Y.K.; Yao, C.J.; Yeh, C.F.; Li, C.H.; Chuang, S.E.; Luong, J.H.; Lai, G.M.; Tzeng, Y.M. Cytotoxic triterpenes from Antrodia camphorata and their mode of action in HT-29 human colon cancer cells. Cancer Lett. 2009, 285, 73-79.

22. Deng, J.Y.; Chen, S.J.; Jow, G.M.; Hsueh, C.W.; Jeng, C.J. Dehydroeburicoic acid induces calcium- and calpain-dependent necrosis in human U87MG glioblastomas. Chem. Res. Toxicol. 2009, 22, 1817-1826.

23. Tsai, W.C.; Rao, Y.K.; Lin, S.S.; Chou, M.Y.; Shen, Y.T.; Wu, C.H.; Geethangili, M.; Yang, C.C.; Tzeng, Y.M. Methylantcinate A induces tumor specific growth inhibition in oral cancer cells via Bax-mediated mitochondrial apoptotic pathway. Bioorg. Med. Chem. Lett. 2010, 20, 6145-1648.

24. Hsieh, Y.C.; Rao, Y.K.; Wu, C.C.; Huang, C.Y.F.; Geethangili, M.; Hsu, S.L.; Tzeng, Y.M. Methyl antcinate A from Antrodia camphorata induces apoptosis in human liver cancer cells through oxidant-mediated cofilin- and Bax-triggered mitochondrial pathway. Chem. Res. Toxicol. 2010, 23, 1256-1267.

25. Shi, L.S.; Chao, C.H.; Shen, D.Y.; Chan, H.H.; Chen, C.H.; Liao, Y.R.; Wu, S.J.; Leu, Y.L.; Shen, Y.C.; Kuo, Y.H.; et al. Biologically active constituents from the fruiting body of Taiwanofungus camphoratus. Bioorg. Med. Chem. 2011, 19, 677-683.

26. Hsieh, Y.C.; Rao, Y.K.; Whang-Peng, J.; Huang, C.Y.F.; Shyue, S.K.; Hsu, S.L.; Tzeng, Y.M. Antcin B and its ester derivative from Antrodia camphorata induce apoptosis in hepatocellular carcinoma cells involves enhancing oxidative stress coincident with activation of intrinsic and extrinsic apoptotic pathway. J. Agric. Food Chem. 2011, 59, 10943-10954.

27. Yu, C.C.; Chiang, P.C.; Lu, P.H.; Kuo, M.T.; Wen, W.C.; Chen, P.; Guh, J.H. Antroquinonol, a natural ubiquinone derivative, induces a cross talk between apoptosis, autophagy and senescence in human pancreatic carcinoma cells. J. Nutr. Biochem. 2012, 23, 900-907. 
28. Tu, S.H.; Wu, C.H.; Chen, L.C.; Huang, C.S.; Chang, H.W.; Chang, C.H.; Lien, H.M.; Ho, Y.S. In vivo antitumor effects of 4,7-dimethoxy-5-methyl-1,3-benzodioxole isolated from the fruiting body of Antrodia camphorata through activation of the p53-mediated p27/Kip1 signaling pathway. J. Agric. Food Chem. 2012, 60, 3612-3618.

29. Lee, Y.P.; Tsai, W.C.; Ko, C.J.; Rao, Y.K.; Yang, C.R.; Chen, D.R.; Yang, M.H.; Yang, C.C.; Tzeng, Y.M. Anticancer effects of eleven triterpenoids derived from Antrodia camphorata. Anticancer Res. 2012, 32, 2727-2734.

30. Lin, T.Y.; Chien, S.C.; Kuo, Y.H.; Wang, S.Y. Distinguishing between R- and S-antcin C and their cytotoxicity. Nat. Prod. Commun. 2012, 7, 835-836.

31. Huang, H.C.; Liaw, C.C.; Yang, H.L.; Hseu, Y.C.; Kuo, H.T.; Tsai, Y.C.; Chien, S.C.; Amagaya, S.; Chen, Y.C.; Kuo, Y.H. Lanostane triterpenoids and sterols from Antrodia camphorata. Phytochemistry 2012, 84, 177-183.

32. Silverstein, R.M.; Webster, F.X.; Kiemle, D.J. Spectrometric Identification of Organic Compounds, 7th ed.; John Wiley \& Sons, Inc.: Hoboken, NJ, USA, 2005; p. 223.

33. Chiu, H.L.; Wu, J.H.; Tung, Y.T.; Lee, T.H.; Chien, S.C.; Kuo, Y.H. Triterpenoids and aromatics from Derris laxiflora. J. Nat. Prod. 2008, 71, 1829-1832.

(C) 2013 by the authors; licensee MDPI, Basel, Switzerland. This article is an open access article distributed under the terms and conditions of the Creative Commons Attribution license (http://creativecommons.org/licenses/by/3.0/). 